\title{
Kimberlites, lamproites, carbonatites and associated alkaline rocks: a tribute to the work of Rex T. Prider
}

\author{
L. G. Gwalani ${ }^{1}$ - A. L. Jaques ${ }^{2}$ - P. J. Downes ${ }^{3}$ N. V. Chalapathi Rao ${ }^{4}$
}

Published online: 16 February 2016

(C) Springer-Verlag Wien 2016

This special issue is a tribute to the work of the late Rex T. Prider, who undertook pioneering work on the West Kimberley leucite lamproites and predicted a link to diamonds. The special issue incorporates both authoritative research and significant new contributions to the understanding of the mineralogy and petrology of carbonatites, kimberlites, lamproites and related alkaline rocks. Apart from their scientific interest, these rocks are of major and growing economic importance. They are significant repositories of certain metals and other mineral commodities, indeed the only source of some of them, including diamonds, niobium, the rare-earth elements, copper, phosphate, vermiculite, and raw materials for the manufacture of ceramics. Mining exploration efforts result in the discovery of new localities that add to our understanding of these rocks and their mantle source regions. Not only do such rocks provide a unique sample of the upper

L. G. Gwalani is an Associate Editor and A. L. Jaques, P. J. Downes and N. V. Chalapathi-Rao are Guest Editors

\section{G. Gwalani \\ lgwalani@gmail.com; http://ggwalani.jimdo.com}

A. L. Jaques

Lynton.Jaques@anu.edu.au

1 King River Copper Limited-University of Western Australia, Boronia 26/122 Mounts Bay Road, Mounts Bay Village, Perth, WA 6000, Australia

2 Research School of Earth Sciences, Australian National University, Canberra, ACT 2600, Australia

3 Department of Earth and Planetary Sciences, Western Australian Museum, Locked Bag 49, Welshpool DC, WA 6986, Australia

4 Electron Probe Micro Analyzer (EPMA) Laboratory Centre of Advanced Study in Geology Institute of Science, Banaras Hindu University, Varanasi 221005, India mantle, they also hold many of the clues to understanding the geochemical enrichment of the sub-continental lithosphere, mantle melting, and melt migration and evolution at both mantle and crustal levels. Recent advances in our understanding of these rocks have come from areas including radiogenic and stable isotopes, melt and fluid inclusions, and improved trace-element geochemical techniques applied to the microanalysis of constituent minerals. Progress has also been made in understanding the tectonic setting of alkaline magmatic provinces, mantle metasomatism and evolution, magma generation, and the metallogenesis and hydrothermal alteration of these rocks.

Studies of mantle xenoliths and alkaline rocks, supported by the findings of experimental petrology, suggest that carbonatite melt is a major metasomatic agent in the upper mantle (Yaxley et al. 1998; Giuliani et al. 2012; Litasov et al. 2013). Carbon is recycled into the mantle through the subduction of oceanic crust, and with melting the resultant flux of $\mathrm{CO}_{2}$-rich asthenospheric mantle diapirs up into the lithospheric mantle probably contributes to diamond precipitation and various forms of alkaline magmatism (e.g., carbonatites and kimberlites; Litasov et al. 2013; Tappe et al. 2013). Within the last decade, insights from melt and fluid inclusion studies have seen the proposal of controversial new theories in kimberlite genesis, where the primary kimberlite magma is a $\mathrm{Cl}, \mathrm{S}$, alkali-rich, $\mathrm{Si}$-poor, $\mathrm{Ca}-\mathrm{Mg}$ carbonate liquid that rapidly becomes saturated in olivine as a result of the dissolution of mantle olivine and orthopyroxene during ascent and decompression (e.g., Kamenetsky et al. 2013).

The spectrum of alkaline magmatism present in Precambrian cratons across the globe bears the imprint of cratonic metasomatic histories and suggests that each has a dinstinctive sub-continental lithospheric mantle (SCLM) composition producing regionally unique magma compositions. The melting of metasomatic veins plus wall rock 
peridotite towards the base of the SCLM may be a mechanism for the generation of lamproites, ultramafic lamprophyres (UML), kamafugites and orangeites (group II kimberlites) for example (Tappe et al. 2008; Foley et al. 2002; Tappe et al. 2013; Giuliani et al. 2015). Links between UML and carbonatite magmatism, with the input of asthenospheric melts into the SCLM, in areas such as eastern Canada have been documented (Tappe et al. 2008).

The special issue contains the following papers from eminent workers to highlight advances in these areas, focusing particularly on mantle metasomatism and the generation of alkaline magmas, and links between carbonatites, kimberlites and other cratonic alkaline rock suites. Its principal goal is to spread updated scientific knowledge on the mineralogy and petrology of carbonatites, kimberlites, lamproites and related alkaline rocks. The volume will be beneficial to students and academic researchers (igneous petrologists, economic geologists and geochemists), as well as exploration and mining industry professionals.

The 12 papers in this special issue are broadly arranged in terms of their link to Prider's research contribution with two papers from the Kimberley region of WA - one on the West Kimberley lamproites and another on a large carbonatite - followed by several studies of kimberlites, lamproites and ultrapotassic rocks from India, a sodic alkaline suite from Madagascar, two comprehensive overview studies of carbonatites, two papers on ultra-deep diamonds from Brazil with carbonatitic inclusions, and a study of the origin of zircon megacrysts in alkali basalts of the Indo Pacific.

The first paper (Jaques, this issue) appropriately returns to the West Kimberley, the site of Prider's original studies with a study of the compositional variation in groundmass phases in the olivine and leucite lamproites - chromian spinel, perovskite, ilmenite, priderite, wadeite, jeppeite, and noonkanbahite. Crystallization of these phases and the range in compositions reflects the Al- and Na-poor, ultrapotassic bulk chemistry of the lamproites and their extreme enrichment in $\mathrm{Ti}, \mathrm{Ba}, \mathrm{Sr}, \mathrm{Zr}$ and LREE. Observed variation across the lamproite province and between individual intrusions in spinel and perovskite compositions reflects the degree of magma evolution, temperature and $\mathrm{fO}_{2}$. The largest ranges in mineral chemistry occur in the strongly zoned Walgidee Hills intrusion where perovskite and, to a much lesser extent, priderite show compositional changes towards the slowly cooled centre of the intrusion where late-forming jeppeite and noonkanbahite crystallized from highly evolved, enriched lamproite magma. Perovskite records the evolutionary trend of enrichment in $\mathrm{Na}$, $\mathrm{Sr}, \mathrm{Y}, \mathrm{Nb}, \mathrm{U}$ and REE, and depletion in $\mathrm{Cr}$ and $\mathrm{Fe}$ with magma fractionation.

The second paper is also located in the Kimberley region of Western Australia. Downes et al. (this issue) present results of SHRIMP U-Pb dating of zirconolite in clinopyroxenite from the Cummins Range Carbonatite Complex, in the southern
Halls Creek Orogen that give a reliable ${ }^{207} \mathrm{~Pb} /{ }^{206} \mathrm{~Pb}$ age of emplacement of $1009 \pm 16 \mathrm{Ma}$, some $100 \mathrm{Ma}$ older than thought from previous studies. Variably metamict and recrystallised zircons from co-magmatic carbonatites, gave a similar age but with a larger uncertainty, reflecting partial isotopic resetting during post-emplacement deformation and alteration. Similarly, monazite-(Ce) in deformed dolomite carbonatite yielded $\mathrm{U}-\mathrm{Th}-\mathrm{Pb}$ dates ranging from $\sim 900$ to $590 \mathrm{Ma}$, reflecting a long history of hydrothermal alteration/ recrystallisation that included the apparent resetting of the $\mathrm{Rb}$ $\mathrm{Sr}$ and $\mathrm{K}-\mathrm{Ar}$ isotopic systems by a post-emplacement thermal event at $\sim 900 \mathrm{Ma}$ during the intracratonic Yampi Orogeny. Emplacement appears to have occurred during the amalgamation of Proterozoic Australia with Rodinia over the period $\sim 1000-950 \mathrm{Ma}$, and pre-dates emplacement of kimberlite and ultramafic lamprophyre at the Kimberley Craton margins at $\sim 815-800 \mathrm{Ma}$. There is no evidence of a link between the emplacement of the Cummins Range Carbonatite Complex and mafic large igneous province magmatism or mantle plume activity. Patterns of Proterozoic alkaline magmatism in the Kimberley Craton may have been controlled by changing plate motions during the Nuna-Rodinia supercontinent cycles $(\sim 1200-800 \mathrm{Ma})$.

A wide range of potassic ultramafic rocks variously described as kimberlite, lamproite, ultramafic lamprophyre, and orangeite have been reported from the Dharwar, Bundelkhand, and Bastar Cratons of India, some of which carry diamonds and have been the subject of recent diamond exploration. Many of these intrusions have been shown to have mineralogical and petrological characteristics that pose challenges to their ready petrological classification and to understanding their petrogenesis. Four papers in this issue address this issue.

The first, by Kaur and Mitchell (this issue), re-examines in detail the mineralogy and mineral chemistry of one of the Mesoproterozoic age hypabyssal intrusions from the Wajrakarur area of the Eastern Dharwar Craton of southern India. The authors conclude from texture and the compositions of olivine, phlogopite, spinel, and K-Ti-richterite, together with pseudomorphs after inferred former potassium feldspar, that the P-12 intrusion is an olivine lamproite and not a kimberlite, as previously described. They postulate that this, and other lamproites located adjacent to the Eastern Ghats Mobile Belt, were derived by extensional decompressional melting of ancient subduction zones underlying the cratonic regions.

The second paper, by Chalapathi Rao et al. (this issue), presents mineral chemistry and whole rock major and traceelement geochemistry for a recently discovered suite of Mesoproterozoic $(\sim 1.4 \mathrm{Ga})$ lamproite dykes from the Garledinne (Banganapalle) cluster in the south-western part of the Paleo-Mesoproterozoic Cuddapah Basin in the Eastern Dharwar Craton. These authors show that 
Garledinne lamproites, although subject to extensive alteration, differ from the lamproites of the Eastern Dharwar Craton in their lack of sanidine, clinopyroxene, potassic richterite, and titanite. They also note that although the Garledinne lamproites are commonly inferred to be sources for the diamonds in the nearby Banganapalle conglomerates, this has not been established by sampling of the dykes. The Garledinne lamproites are inferred to have formed as smalldegree partial melts of refractory mantle peridotite previously enriched by carbonate-rich fluids/melts with both the subcontinental lithospheric mantle and asthenosphere sources involved. Emplacement of the Garledinne lamproites probably was related to extensional events during the break-up of the Columbia supercontinent.

The third paper (Chalapathi Rao et al., this issue) reports mineralogical, geochemical, ${ }^{40} \mathrm{Ar} /{ }^{39} \mathrm{Ar}$ (whole-rock) age and $\mathrm{Sr}$ and $\mathrm{Nd}$ isotopic data for a Mesoproterozoic ultrapotassic dyke from the Nuapada lamproite field at the tectonic contact between the easternmost margin of the Bastar craton and Eastern Ghats Mobile Belt in northern India. The Sakri dyke mineralogically resembles lamproites but has a major element rock chemistry (notably extreme silica-undersaturation) comparable with kamafugites from Toro Ankole in the East African Rift, and the Alto Paranaiba Province in Brazil. The ${ }^{40} \mathrm{Ar} /{ }^{39} \mathrm{Ar}$ age $(1045 \pm 9 \mathrm{Ma})$ is broadly similar to that of other Mesoproterozoic lamproites from the Bastar and Bundelkhand cratons, and kimberlites from the Eastern Dharwar craton. The radiogenic initial $\mathrm{Sr}$ and unradiogenic $\mathrm{Nd}$ isotopic compositions suggest involvement of an 'enriched' source region with long-term incompatible element enrichment and an ancient depleted mantle ( $\mathrm{T}_{\mathrm{DM}} \mathrm{Nd}$ model age $=2.56 \mathrm{Ga}$ ). Emplacement of the Sakri ultrapotassic dyke is linked to a widespread $1.1 \mathrm{Ga}$ tectonomagmatic event related to extension associated with the amalgamation of the Rodinia supercontinent. However, its overlapping geochemical characteristics of lamproite and kamafugite are thought to be due to its emplacement in a unique geological setting at the craton-mobile belt boundary.

A fourth paper by Dongre et al. (this issue) describes an occurrence of Ti-rich garnets in the groundmass of two kimberlites from the diamondiferous Wajrakarur field in the Eastern Dharwar Craton. These garnets, unusual in kimberlite, contain considerable $\mathrm{Ti}, \mathrm{Ca}$, and $\mathrm{Cr}$ but have low $\mathrm{Al}$ contents. They range in compositions from andradite to schorlomite: the garnets with significant $\mathrm{Cr}$ represent a solid solution between schorlomite and uvarovite. The Ti-rich garnets are intimately associated with chrome-spinels and are inferred to have formed by reaction of early magmatic spinels with late circulating, residual fluids in the final stages of crystallisation of the kimberlite magma. The authors review the occurrence of similar Ti-rich garnets in kimberlites and related rocks, notably ultramafic lamprophyres, and explore possible petrogenetic links between them.
Cucciniello et al. (this issue) present new Ar-Ar ages and mineralogical and geochemical data for the Cenozoic alkali basalts and basanites, nepheline syenites and phonolites, and silica saturated-to-oversaturated syenites, trachytes, granites and rhyolites of the Ampasindava Peninsula and Nosy Be archipelago of northern Madagascar. Mantle-normalized incompatible element patterns of the mafic lavas match those of Na-alkaline lavas in within-plate rift settings. The authors ascribe the extreme range of this sodic suite to fractional crystallization processes involving removal of olivine, feldspars, clinopyroxenes, amphibole, Fe-Ti oxides and apatite from mafic parental magmas and/or open system processes in shallow magmatic reservoirs. Removal of small amounts of titanite is suggested to explain the concave upward REE pattern in the evolved nepheline syenites and phonolites, which are additionally rich in the exotic silicates typical of agpaitic magmas (eudialyte, F-disilicates). The mafic magmas of northern Madagascar have a similar trace element-enriched geochemistry and are interpreted to indicate derivation by small but variable proportions (2-10\%) of partial melting of similar amphibole and phlogopite-bearing mantle at slightly different depths.

In the first of two papers on carbonatites in this issue Chakhmouradian et al. (this issue) address the issue of textures in carbonatites with a review, well supported by photographs and SEM images, describing the major (micro)textural characteristics of carbonatitic calcite and dolomite in the context of magma evolution, fluid-rock interaction, or deformation, and provide information on the compositional variation of these minerals and its relation to specific evolutionary processes. The authors point out that, while carbonatites are nominally igneous rocks, their evolution commonly also involves a variety of postmagmatic processes, including exsolution, subsolidus re-equilibration of igneous mineral assemblages with fluids of different provenance, hydrothermal crystallization, recrystallization and tectonic mobilization. The authors stress that, because postmagmatic processes can result in substantial modification of the rock, petrogenetic interpretation of carbonatites (and more applied aspects such as assessment of their mineral potential) require an understanding of the textural and compositional effects of both magmatic and postmagmatic processes on the principal constituents of these rocks.

In a companion paper Chakhmouradian et al. (this issue) examined the trace element variations in calcite and dolomite in several carbonatite complexes to assess the extent of substitution of REE and other trace elements in these minerals and the impacts of different igneous and postmagmatic processes on their composition. The data show that REE abundances and certain REE ratios in magmatic calcite and dolomite are controlled by crystal fractionation of fluorapatite, monazite and, possibly, other minerals. The authors also found the distribution of large-ion-lithophile elements $(\mathrm{Sr}, \mathrm{Ba}$ and $\mathrm{Pb})$ in 
rock-forming carbonates similarly shows trends indicative of crystal fractionation effects although the phases responsible for these variations could be identified unambiguously. Overall, element ratios sensitive to the redox state of the magma and its complexing characteristics $\left(\mathrm{Eu} / \mathrm{Eu}^{*}, \mathrm{Ce} / \mathrm{Ce} *\right.$ and $\mathrm{Y} / \mathrm{Ho}$ ) were found to be least variable and in both primary calcite and dolomite, and approximate average chondritic values. Calcite invariably has higher REE and LILE levels than co-existing dolomite. Hydrothermal alteration did not produce a unique geochemical fingerprint but rather a variety of evolutionary trends ranging from LREE and LILE enrichment to HREE enrichment and LILE depletion, reflecting variations in the chemistry of carbonatitic fluids and their ability to mobilize specific trace elements from earlier-crystallized minerals.

Two papers by Kaminsky et al. (this issue) deal with ultradeep diamonds from the Juina area in the Mato Grosso State of Brazil. The first of these reviews the diverse assemblage of carbonate and associated $\mathrm{Ca}$-mineral inclusions reported from the Juina diamonds and presents an analysis of the conditions of formation and the source(s) of the carbonatitic material. The mineral inclusions comprise almost 50 mineral species: carbonates, halides, fluorides, phosphates, sulfates, oxides, silicates, sulfides and native elements. Key amongst the inclusions are periclase and wüstite, indicating an ultradeep origin for the diamonds. The authors argue that the inclusions formed from a carbonatitic melt and that they define a primary natrocarbonatitic association in the lower mantle in addition to ultramafic and mafic paragenesis. The authors propose a model for the formation and evolution of carbonatite melts in the deep mantle in which an initial lower mantle carbonatitic melt rich in $\mathrm{P}, \mathrm{F}, \mathrm{Cl}$ and other volatile elements forms as a result of low fraction partial melting of lower mantle material at the core - mantle boundary. During ascent to the surface the initial carbonatitic melt dissociates into two immiscible parts, a carbonate - silicate and a chloride - carbonate melt, with this latter melt giving rise to the natrocarbonatitic association. Diamonds with carbonatitic inclusions are inferred to have formed in carbonatitic melts or high-density fluids.

The second paper (Kaminsky et al. this issue) presents results from a study by NanoSIMS of two Juina diamonds with inclusions of calcite + wollastonite and calcite + monticellite which are inferred to have formed by decomposition of a lower-mantle assemblage of calcite $+\mathrm{CaSi}$-perovskite + volatiles during the course of the diamond ascent from pressures of $\sim 15$ to less than $0.8 \mathrm{GPa}$. Oxygen and carbon isotopic compositions of the studied minerals are inhomogeneous with a wide range $\left(\delta^{18} \mathrm{O}=-3.3 \%\right.$ to $+15.4 \%$ sMow and $\delta^{13} \mathrm{C}=-2.8$ $\%$ to $+9.3 \%$ VPDB $)$ thought to be due to fractionation during decomposition of the primary phases.

The final paper by Sutherland et al. (this issue) integrates age-dating, trace element, and oxygen and hafnium isotope data to examine the origin of zircon megacrysts $( \pm$ gem corundum) in various basalt fields over a $12,000 \mathrm{~km}$ zone along West Pacific continental margins. The authors conclude that the data indicate diverse magmatic and probably alkaline sources. The zircon megacrysts have O-isotope ratios and initial $\mathrm{Hf}$ isotope ratios that encompass ranges for both mantle and crustal melts, and abundances and abundance ratios of key trace elements that match those in zircons from a range of ultramafic to felsic rocks. Ti - in - zircon thermometry suggests that most zircons crystallized at temperatures of 550 to $830^{\circ} \mathrm{C}$. Large differences observed between the U$\mathrm{Pb}$ ages and zircon fission track ages suggest post-formation thermal annealing occurred during their later eruption in basalts. The authors propose, based on isotopic model ages, that several mantle events, including breakup of Rodinia and Gondwana and convergent margin collisions, have left imprints in the zircon source melts. They suggest that the East Australian zircon sites reflect prolonged intraplate magmatism ( $\sim 85 \mathrm{Ma})$, often during times of fast-migrating lithosphere whereas the East Asian-Russian sites reflect later basaltic magmatism ( $<40 \mathrm{Ma})$, often linked to episodes of back-arc rifting and spreading, slow-migrating lithosphere and slab subduction.

Acknowledgments The Associate editor and Guest editors of this special issue wish to thank the Editors-in-chief of the journal, Johann G. Raith and Lutz Nasdala, for supporting this special issue as a dedication to the late Professor Rex Prider and their patience in its preparation. We also thank the scientists who reviewed the papers submitted to this special issue and Lhiric Agoyaoy and members of the Springer Journals Editorial Office for their assistance in their publication.

We are grateful to the many individuals who have given of their time, energy and expertise in the production process of this volume. We wish to thank authors for their contributions. We are indebted to the following individuals (listed in alphabetical order) for reviewing the papers included in this volume:

Dejan Prelevic

Felix Kaminsky

Franco Pirajno

Francesco Stoppa

GirardiVicente

Greg Yaxley

Heilimo Esa

Hugh O'Brien

Kirtikumar Randive

Kosiyathu-Raghavan Hari

Lalchand Gwalani

Lia Kogarko

Lynton Jaques

Marion Bickford

Maya Kopylova

Nittala-Venkata Chalapathi Rao

Peter Downes

Piero Comin-Chiaramonti

Robert Pidgeon

Roger Mitchell

Sam Sethna

Steve Sheppard

Srivastava Singh

Sisir Mondal

Yamuna Singh 
L.G. Gwalani (Lalou) would like to thank Anthony Barton, Ken Rogers, Andrew Chapman, Dhananjay Wanjari, Thomas Valladares, M. Govindram, Jyoti and Shradha Gwalani, Gurmukh Babani, Girish Masand, Amrit Baath, Kirtikumar Randive, Shishir Wasu, Deepak Vaidya and Kumade Dejari for the generous help, facility, support, and cooperation extended while working on this volume.

Finally he (Lalou) would like to convey gratitude to Hazur Shri Baba ji whose constant source of tremendous encouragement and help allowed to complete the work on this volume.

\section{References}

Foley SF, Andronikov AV, Melzer S (2002) Petrology of ultramafic lamprophyres from the beaver lake area of eastern antarctica and their relation to the breakup of Gondwanaland. Mineral Petrol 74: 361-384

Giuliani A, Kamenetsky VS, Phillips D et al (2012) Nature of alkalicarbonate fluids in the sub-continental lithospheric mantle. Geologija 40:967-970. doi:10.1130/G33221.1

Giuliani A, Phillips D, Woodhead JD (2015) Did diamond-bearing orangeites originate from MARID-veined peridotites in the lithospheric mantle? Nat Commun 6:1-10, http://doi.org/10.1038/ ncomms 7837

Kamenetsky VS, Grütter H, Kamenetsky MB, Gömann K (2013) Parental carbonatitic melt of the koala kimberlite (Canada): constraints from melt inclusions in olivine and Cr-spinel, and groundmass carbonate. Chem Geol 353:96-111. doi:10.1016/j.chemgeo. 2012.09.022

Litasov KD, Shatskiy A, Ohtani E, Yaxley GM (2013) Solidus of alkaline carbonatite in the deep mantle. Geologija 41:79-82. doi:10.1130/ G33488.1

Tappe S, Foley SF, Kjarsgaard BA (2008) Between carbonatite and lamproite-diamondiferous torngat ultramafic lamprophyres formed by carbonate-fluxed melting of cratonic MARID-type metasomes. Geochim Cosmochim Acta 72:3258-3286. doi:10. 1016/j.gca.2008.03.008

Tappe S, Pearson DG, Prelevic D (2013) Kimberlite, carbonatite, and potassic magmatism as part of the geochemical cycle. Chem Geol 353:1-3

Yaxley GM, Green DH, Kamenetsky V (1998) Carbonatite metasomatism in the southeastern Australian lithosphere. J Petrol 39:19171930. doi:10.1093/petrology/39.11.1917 